\title{
Papers
}

\section{Psychosocial and psychological interventions for prevention of postnatal depression: systematic review}

Cindy-Lee Dennis

\begin{abstract}
Objective To assess the effects of psychosocial and psychological interventions compared with usual antepartum, intrapartum, or postpartum care on the risk of postnatal depression.

Data sources Medline, Embase, CINAHL, Cochrane central register of controlled trials, Cochrane pregnancy and childbirth group trials register, Cochrane depression, anxiety, and neurosis trials register, secondary references and review articles, and experts in the field.

Study selection All published and unpublished randomised controlled trials of preventive psychosocial or psychological interventions in which the primary or secondary aim was a reduction in the risk of postnatal depression. All trials recruited pregnant women or new mothers less than six weeks postpartum. Eligible studies were abstracted, assessed for methodological quality, and pooled with relative risk for categorical data and weighted mean difference for continuous data.

Results Fifteen trials with 7697 women were included. Although there was no overall statistically significant effect on the prevention of postnatal depression in the meta-analysis of all types of interventions ( 15 trials, $\mathrm{n}=7697$; relative risk 0.81 , $95 \%$ confidence interval 0.65 to 1.02), these results suggest a potential reduction in postnatal depression. The only intervention to have a clear preventive effect was intensive postpartum support provided by a health professional $(0.68$, 0.55 to 0.84 ). Identifying women "at risk" assisted in the prevention of postnatal depression ( $0.67,0.51$ to 0.89 ). Interventions with only a postnatal component were more beneficial $(0.76,0.58$ to 0.98$)$ than interventions that incorporated an antenatal component. In addition, individually based interventions were more effective $(0.76,0.59$ to 1.00$)$ than group based interventions (1.03, 0.65 to 1.63$)$.

Conclusions Diverse psychosocial or psychological interventions do not significantly reduce the number of women who develop postnatal depression. The most promising intervention is the provision of intensive, professionally based postpartum support.
\end{abstract}

\section{Introduction}

Postnatal depression is a major health issue for many women from diverse cultures. ${ }^{12}$ Although longitudinal and epidemiological studies have yielded varying prevalence rates, a meta-analysis of 59 studies reported a prevalence of $13 \%,{ }^{3}$ with most cases starting in the first three months postpartum. ${ }^{4}$ This morbidity has well documented health consequences for the mother, child, and family. Women who have postnatal depression are significantly more likely to experience future episodes of depression, ${ }^{5}$ and infants and children are particularly vulnerable because of impaired maternal-infant interactions and negative perceptions of infant behaviour.

The cause of postnatal depression remains unclear, ${ }^{6}$ with extensive research suggesting many contributory factors. Epidemiological studies and meta-analyses of predictive studies, however, have consistently identified the importance of psychosocial and psychological risk factors ${ }^{367}$ - such as life stress, ${ }^{37-9}$ marital conflict, $^{37-10}$ maternal self esteem, ${ }^{71}$ and lack of social support. $^{37911-15}$ A comprehensive review suggested that in women with postnatal depression, psychosocial and psychological treatment may be suitable. ${ }^{16}$ As such, it is theoretically possible that these interventions may also prevent postnatal depression, as many of the known risk factors are present during pregnancy and the immediate postpartum period. There have been two critical reviews of preventive trials ${ }^{17}{ }^{18}$ and one systematic review that examined diverse interventions to reduce "probable depression" in the postnatal period. ${ }^{19}$ However, no systematic review has examined the overall preventive effect of psychosocial and psychological interventions or determined which characteristics are most beneficial.

I assessed the effects of such interventions compared with usual antepartum, intrapartum, or postpartum care on the risk of postnatal depression. This systematic review is based on a full review published in the Cochrane Library. ${ }^{20}$

\section{Methods}

\section{Searches}

I searched the Cochrane pregnancy and childbirth group trials register. This database contains trials identified from quarterly searches of the Cochrane central register of controlled trials, monthly searches of Medline and hand searches of 30 journals and the proceedings of major conferences. In addition, the Cochrane depression, anxiety, and neurosis trials register, Medline (1966-2004), Embase (1980-2004), and CINAHL (1982-2004) were all independently searched. Secondary references and review articles were scanned and experts in the field were contacted. Trials published in all languages were considered.

\section{Selection}

Published and unpublished studies were eligible if they were randomised controlled trials; were methodologically strong based on a validity assessment; evaluated a psychosocial or psychological intervention in which the primary or secondary aim was a reduced risk of postnatal depression; and included 
pregnant women and new mothers less than six weeks postpartum. I excluded studies if they incorporated a quasi-randomised design; recruited women identified with symptoms of depression, or solely evaluated an educational intervention. For this review, a psychosocial or psychological intervention incorporated various non-pharmaceutical strategies that were delivered antenatally or within the first month postpartum, or both, by a health professional or layperson.

\section{Assessment of validity}

The methodological quality of each trial was assessed according to the recommendations of the Cochrane Collaboration and examined the generation of allocation sequence; allocation concealment; blinding of outcome assessors; completeness of follow-up data; and intention to treat analysis. Two reviewers independently assigned a quality rating to each trial; results were compared and differences discussed until agreement was obtained.

\begin{abstract}
ion of data
Two reviewers independently extracted data and included study design; participants (number and characteristics); intervention type, mode, onset, duration, and provider; outcomes measured; and results. Wherever necessary, unpublished or missing data were requested from the trial's corresponding author and data were double entered into Review Manager version 4.2.3 (Cochrane Collaboration software).
\end{abstract}

\section{Quantitative data synthesis}

While the primary meta-analysis was based on the occurrence of postnatal depression (however measured by trialists), several depression rating scales or cut-off points were incorporated. To address the potential measurement differences, I made direct comparisons using a fixed effect model between trials using the same rating scale and cut off. Meta-analyses were performed using relative risks as the measure of effect size for binary outcomes and weighted mean differences for continuous outcome measures, both with $95 \%$ confidence intervals.

Heterogeneity was investigated by calculating $I^{2}$ statistics, ${ }^{21}$ and if this indicated a high level among the trials included in an analysis $\left(I^{2}>50 \%\right)$, a random effects meta-analysis was used. Where I found high levels of heterogeneity I used sensitivity analyses, excluding the trials most susceptible to bias based on the following quality assessment: those with unclear allocation concealment, high levels of losses or exclusions after randomisation, or uncertain on no blinding of outcome assessment. A priori subgroup analyses estimated the effect of intervention type (for example, psychosocial and psychological), intervention mode (for example, individual $v$ group based), intervention onset (for example, antenatal and postnatal $v$ postnatal only), and sample selection criteria (for example, targeting women with specific risk factors $v$ a general population).

\section{Results}

The search identified 155 studies, of which 99 were excluded as non-experimental. Of the 56 trials retrieved for a more detailed evaluation, 15 studies were of treatment interventions for postnatal depression. The 41 remaining potentially appropriate trials were examined for inclusion/exclusion criteria and methodological quality. I excluded 26 trials because of a quasi-experimental design $(\mathrm{n}=4),{ }^{22-25}$ poor methodological quality $(\mathrm{n}=3),{ }^{26-28}$ not a psychosocial or psychological intervention $(n=12),{ }^{29-40}$ the prevention of postnatal depression was not the primary or secondary objective $(n=5),{ }^{41-45}$ and the interven- tion was for the treatment of antenatal depression $(n=2)^{4647}$ (table 1).

\section{Study characteristics}

The 15 trials in the meta-analysis incorporated 7697 women and were published between 1995 and 2003 (table 2). Most trials were conducted in Australia and the United Kingdom; two trials were conducted in the United States ${ }^{48}{ }^{49}$ and one in China ${ }^{50}$ Seven trials targeted women believed to be at additional risk of postnatal depression, ${ }^{48-54}$ while the eight others enrolled women from the general population.

\section{Types of interventions}

The studies were subgrouped into categories to examine specific types of psychosocial interventions-such as antenatal and postnatal classes ${ }^{52}{ }^{53}{ }^{55}$ professional ${ }^{51}{ }^{56}$ and lay ${ }^{57}$ home visits, continuity of care $^{58}$ and early postpartum follow-up (for example, postpartum care initiated earlier than usual practice $)^{59}$-and psychological interventions, such as debriefing ${ }^{50}{ }^{54}$ 60-62 and interpersonal psychotherapy. ${ }^{48}$ The interventions were provided by various professionals, including physicians, ${ }^{59}$ nurses, ${ }^{50-52}$ midwives, ${ }^{53-56} 5860-62$ and other healthcare providers. ${ }^{48}{ }^{52}$ In one trial, the intervention was provided by lay women recruited from the community. ${ }^{57}$ In most studies, the control group was reported to have received usual antenatal/postnatal care, which varied both between and within countries.

\section{Definition of postnatal depression}

In all trials but one, ${ }^{49}$ postnatal depression was defined as a score above a specified cut-off point on a self reported measure. Most studies (10 out of 15) used an Edinburgh postnatal depression scale score $>12$ to indicate postnatal depression. Two additional trials used the Edinburgh postnatal depression scale but incorporated a different cut off score; one study used a 10/11 cut off ${ }^{52}$ while another selected a 11/12 cut off. ${ }^{55}$ Several studies also reported mean scores using this measure. ${ }^{485155-575960}$ The Edinburgh postnatal depression scale does not diagnose postnatal depression (as this can be accomplished only through a psychiatric clinical interview) but rather it is the most commonly used instrument to assess postpartum depressive symptoms. ${ }^{7}$ Two trials used the self reported hospital anxiety depression scale, ${ }^{5061}$ and two studies used a semistructured diagnostic interview (structured clinical interview for DSM-IV). ${ }^{48}$ The timing of the outcome assessment varied considerably between studies, ranging from three $e^{61}$ to $24^{48535557596062}$ weeks postpartum; one trial also included a 52 week assessment. ${ }^{62}$

\section{Methodological quality}

Randomisation was often with consecutively numbered, sealed, opaque envelopes. ${ }^{50} 535457586162$ Four trials used various forms of computer based randomisation. ${ }^{515255}{ }^{56}$ Two trials incorporated a central computerised randomisation service accessed by telephone ${ }^{5960}$ and one trial used a block randomisation procedure using a random numbers table ${ }^{48}$; one trial was cluster randomised. ${ }^{56}$ Allocation concealment was unclear in one trial. ${ }^{49}$ All but two trials ${ }^{48}{ }^{49}$ completed a power analysis, and data were analysed with an intention to treat approach. Outcome data were collected by assessors blinded to group allocation ${ }^{48}{ }^{51}$ or mailed questionnaires; one study did not identify the outcome assessor. ${ }^{49}$ Five trials had a follow-up attrition rate $>20 \%$ at final study assessment. ${ }^{50} 5565759$ Follow-up in all these trials included mailed questionnaires. Based on susceptibility to bias (for example, unclear allocation concealment, high levels of exclusions or attrition after randomisation, or unblinded outcome assessment), I excluded six trials as appropriate during the sensitivity 


\begin{tabular}{|c|c|}
\hline Study & Reason for exclusion \\
\hline Buist $^{26}$ & $\begin{array}{l}\text { Methodologically weak pilot trial }(n=44) \text { with unclear randomisation method. Significant group differences in baseline characteristics. No usable outcome data; published } \\
\text { data were mean scores without SD }\end{array}$ \\
\hline $\mathrm{Chabrol}^{22}$ & Not randomised controlled trial. Odd $v$ even number group assignment. Data not analysed with intention to treat \\
\hline Elliott $^{23}$ & $\begin{array}{l}\text { Not randomised controlled trial. Group allocation based on delivery date. Potential selection bias with significant differences between participating and non-participating } \\
\text { eligible women. Data presented with median instead of mean results }\end{array}$ \\
\hline Gordon ${ }^{24}$ & $\begin{array}{l}\text { Not randomised controlled trial. Inexplicit non-random group allocation. Primary outcome was "emotional upset" with subjective measure. Characteristics of participants } \\
\text { lacking and } 46 \% \text { of mothers lost to follow-up }\end{array}$ \\
\hline Gordon ${ }^{41}$ & $\begin{array}{l}\text { Postnatal depression not the primary or secondary outcome. Poor measure of postnatal depression that included single item question and subscore on mental health } \\
\text { index of SF-36. In addition, 30\% women excluded after randomisation }\end{array}$ \\
\hline Harris $^{29}$ & Intervention not psychosocial or psychological; examined effect of thyroxine to prevent postnatal depression among thyroid-antibody-positive women \\
\hline Harrison-Hohner ${ }^{30}$ & Intervention not psychosocial or psychological; examined effect of prenatal calcium supplementation. Postnatal depression was not primary or secondary outcome \\
\hline Hayes $^{31}$ & Intervention not psychosocial or psychological; included single educational session about postnatal depression, provided antenatally by midwife \\
\hline $\mathrm{Heh}^{32}$ & Intervention not psychosocial or psychological; included only information related to postnatal depression \\
\hline Hodnett ${ }^{42}$ & Postnatal depression not primary or secondary outcome \\
\hline Lawrie $^{34}$ & Intervention not psychosocial or psychological; examined effect of norethisterone enanthate (progesterone therapy) \\
\hline Lieu $^{43}$ & Premature assessment of postnatal depression (two weeks after delivery), which was neither primary or secondary outcome \\
\hline Llorente $^{33}$ & Intervention not psychosocial or psychological; examined effect of docosahexaenoic acid supplementation \\
\hline Marks $^{27}$ & $\begin{array}{l}\text { Methodologically weak for "prevention" trial. About } 25 \% \text { of participants were currently suffering from depression at recruitment and } 49 \% \text { had depressive episode } \\
\text { sometime during perinatal period }\end{array}$ \\
\hline Okano ${ }^{35}$ & $\begin{array}{l}\text { Intervention not psychosocial or psychological; study examined educational session retrospectively involving two non-randomised groups of women who sought } \\
\text { psychiatric care postnatally }\end{array}$ \\
\hline Rees $^{36}$ & Intervention not psychosocial or psychological; examined effect of relaxation with guided imagery \\
\hline Saisto $^{44}$ & Postnatal depression not primary or secondary outcome; statistical results related to postnatal depression not reported \\
\hline Serwint ${ }^{25}$ & Not randomised controlled trial. Group allocation based on two week period \\
\hline Shields ${ }^{45}$ & $\begin{array}{l}\text { Study reports on element of larger trial where primary and secondary outcome was not postnatal depression. One item on Edinburgh scale (self harm) excluded, } \\
\text { rendering clinical interpretability of outcome data questionable }\end{array}$ \\
\hline Sichel ${ }^{37}$ & Intervention not psychosocial or psychological; examined effect of oestrogen therapy \\
\hline Spinelliti & Intervention targeting treatment of antenatal depression not prevention of postnatal depression \\
\hline Spinelli ${ }^{47}$ & Intervention targeting treatment of antenatal depression not prevention of postnatal depression \\
\hline Webster $^{38}$ & $\begin{array}{l}\text { Intervention not psychosocial or psychological; included antenatal identification as high risk, educational booklet and discussion about risk of developing postnatal } \\
\text { depression, and letter to woman's referring general practitioner and local child health nurse alerting them of woman's risk }\end{array}$ \\
\hline Wolman ${ }^{28}$ & $\begin{array}{l}\text { Methodologically weak trial. Researchers significantly changed study protocol before trial completion. Inability to assess selection bias. Trial had } 21 \% \text { loss to follow-up } \\
\text { and poor measure of postnatal depression (Pitt depression inventory) used for main portion of trial }\end{array}$ \\
\hline Wisner $^{39}$ & Intervention was not psychosocial or psychological; examined effect of antidepressant medication \\
\hline Wisner ${ }^{40}$ & Intervention was not psychosocial or psychological; examined effect of antidepressant medication \\
\hline
\end{tabular}

analysis for outcomes with high levels of heterogeneity $\left(I^{2}>50 \%\right)^{49}{ }^{50} 55-5759$

\section{Quantitative data synthesis}

\section{Postnatal depression at last assessment}

Variously defined-My main outcome measure was postnatal depression at the last study assessment. Although there was no statistically significant beneficial effect on the prevention of postnatal depression in the meta-analysis of all types of interventions (15 trials, $\mathrm{n}=7697$; relative risk $0.81,95 \%$ confidence interval 0.65 to 1.02 ) (fig 1), these results suggest a potential $19 \%$ reduction in postnatal depression. There was significant heterogeneity among these trials $\left(I^{2}=68.8 \%\right)$. The removal of trials at risk of bias, however, resulted in no substantial change to the conclusion. I found a similar non-significant effect when I calculated a weighted mean difference (WMD) among the trials that provided a mean score on the Edinburgh postnatal depression scale (seven trials, $\mathrm{n}=3300$; WMD $-0.06,-0.37$ to 0.26 ) (fig 2).

Edinburgh postnatal depression score $>12-$ To examine potential measurement differences, I used a random effects model to directly compare trials that used the Edinburgh postnatal depression scale with the recommended 12/13 cut-off score $^{63}$ and found no preventive effect (10 trials, $\mathrm{n}=6126 ; 0.91$, 0.73 to 1.15$)$.

\section{Postnatal depression at 8,16, and 24 weeks}

Variously defined-To assess the short and longer term effects of the preventive interventions, I categorised assessments of postnatal depression at $0-8$ weeks postpartum (short term effect); 9-16 weeks (intermediate effect); and 17-24 weeks (longer term effect). Results showed a short term reduction in the development of postnatal depression (eight trials, $\mathrm{n}=4091 ; 0.65,0.43$ to 1.00 ). The effect weakened at the intermediate period (eight trials, $\mathrm{n}=3326 ; 0.80,0.56$ to 1.12$)$ and disappeared after 16 weeks (seven trials, $\mathrm{n}=4314 ; 1.02,0.87$ to 1.19 ).

Edinburgh postnatal depression scale score $>12$-When I included only those trials that used an Edinburgh postnatal depression scale score $>12$ as the outcome measure, there were no statistically significant short term (six trials, $\mathrm{n}=3452 ; 0.90$, 0.65 to 1.25 ), intermediate (five trials, $\mathrm{n}=2369 ; 0.72,0.49$ to 1.06 ), or longer term (six trials, $\mathrm{n}=3598 ; 1.00,0.84$ to 1.19 ) effects.

\section{Subgroup analyses}

Type of intervention - I found no preventive effect with antenatal and postnatal classes (two trials, $\mathrm{n}=311 ; 1.02,0.61$ to 1.72 ), lay home visits (one trial, $\mathrm{n}=481 ; 0.89,0.62$ to 1.27 ), and early postpartum follow-up (one trial, $\mathrm{n}=475 ; 0.91,0.56$ to 1.48 ). I did, however, find a positive trend related to continuity of care (one trial, $\mathrm{n}=935 ; 1.34,0.97$ to 1.85 ) and a clear beneficial effect with home visits provided by a health professional (two trials, $\mathrm{n}=1663 ; 0.68,0.55$ to 0.84 ). Among psychological interventions, there was no preventive effect in relation to interpersonal psychotherapy (two trials, $\mathrm{n}=72 ; 0.31,0.04$ to 2.52 ) but a positive trend in relation to debriefing in hospital (five trials, $\mathrm{n}=3051$; $0.57,0.31$ to 1.04$)$.

Mode of intervention - Analysis of 11 trials evaluating individually based interventions showed a benefit in preventing postnatal 
depression at the last study assessment $(\mathrm{n}=6642 ; 0.76,0.59$ to 1.00). When I excluded trials susceptible to bias, the direction of the effect remained the same but the confidence interval widened (seven trials, $\mathrm{n}=3667 ; 0.68,0.43$ to 1.09 ). Of the four trials that evaluated group based interventions, there was no apparent reduction in depressive symptoms at last study assessment $(\mathrm{n}=1055 ; 1.03,0.65$ to 1.63$)$.

\begin{tabular}{|c|c|c|c|c|c|}
\hline Study & Methods (all RCTs) & Participants & Interventions & Outcome & Notes \\
\hline Armstrong $^{51}$ & $\begin{array}{l}\text { Randomisation performed with } \\
\text { computer generated random } \\
\text { numbers table and completed by } \\
\text { clerical staff not involved in } \\
\text { eligibility assessment. Power } \\
\text { analysis performed and outcome } \\
\text { assessor blinded to group } \\
\text { allocation. Nurses providing } \\
\text { intervention blinded to six weeks } \\
\text { postpartum (within usual care } \\
\text { parameters). Attrition rate 12\% at } \\
16 \text { weeks }\end{array}$ & $\begin{array}{l}181 \text { mothers (90 in intervention; } \\
91 \text { in control) who gave birth in } \\
\text { one urban hospital in Queensland, } \\
\text { Australia. Families were included } \\
\text { where child, for environmental } \\
\text { reasons, was at increased risk for } \\
\text { poor health and developmental } \\
\text { outcomes }\end{array}$ & $\begin{array}{l}\text { Intervention: weekly nursing } \\
\text { home visits for first } 6 \text { weeks, } \\
\text { fortnightly until } 12 \text { weeks, then } \\
\text { monthly until } 24 \text { weeks. Mothers } \\
\text { also encouraged to access } \\
\text { existing community services } \\
\text { Control: standard care, included } \\
\text { encouragement to access existing } \\
\text { community services, offer of } \\
\text { home visits by nurse (usually } \\
\text { limited to one visit), and no limit } \\
\text { on number of centre visits (by } \\
\text { appointment only) }\end{array}$ & $\begin{array}{l}\text { EPDS }>12 \text { at } 6 \text { and } \\
16 \text { weeks } \\
\text { postpartum }\end{array}$ & $\begin{array}{l}\text { Only } 63 \% \text { of mothers completed } \\
\text { screening questionnaire before } \\
\text { trial }\end{array}$ \\
\hline Brugha $^{52}$ & $\begin{array}{l}\text { Randomisation performed with } \\
\text { computer based stratification } \\
\text { process with minimisation on } \\
\text { three prognostic factors (level of } \\
\text { support, screening, and ethnic } \\
\text { group). Power analysis performed } \\
\text { and outcome assessors blinded to } \\
\text { group allocation. Attrition rate } 9 \% \\
\text { at } 12 \text { weeks }\end{array}$ & $\begin{array}{l}209 \text { pregnant women (103 in } \\
\text { intervention; } 106 \text { in control) who } \\
\text { attended antenatal clinics in UK } \\
\text { hospital between } 12 \text { and } 20 \\
\text { weeks' gestation identified by } \\
\text { screening to be at increased risk } \\
\text { of postnatal depression }\end{array}$ & $\begin{array}{l}\text { Intervention: Preparing for } \\
\text { Parenthood-six structured two } \\
\text { hour weekly antenatal classes } \\
\text { (preceded by initial introductory } \\
\text { meeting with participant and her } \\
\text { partner) and one reunion class at } \\
\text { eight weeks postpartum. Classes } \\
\text { provided by trained nurse and } \\
\text { occupational therapist and based } \\
\text { on established psychological } \\
\text { models for tackling depression } \\
\text { together with emerging models } \\
\text { for enhancing social support }\end{array}$ & $\begin{array}{l}\text { EPDS }>10 \text { at } 12 \\
\text { weeks postpartum }\end{array}$ & $\begin{array}{l}\text { Only } 45 \% \text { of participants in } \\
\text { intervention group attended } \\
\text { enough sessions to "likely receive } \\
\text { benefit" }\end{array}$ \\
\hline Gamble $^{54}$ & $\begin{array}{l}\text { Randomisation performed with } \\
\text { consecutively numbered, sealed, } \\
\text { opaque envelopes. Power analysis } \\
\text { conducted and outcome assessor } \\
\text { blinded to group allocation. } \\
\text { Attrition rate } 0 \% \text { at } 12 \text { weeks }\end{array}$ & $\begin{array}{l}103 \text { mothers (50 in intervention; } \\
53 \text { in control) assessed for labour } \\
\text { trauma risk in immediate } \\
\text { postpartum period in hospital in } \\
\text { Brisbane, Australia }\end{array}$ & $\begin{array}{l}\text { Intervention: one midwife-led } \\
\text { debriefing session before hospital } \\
\text { discharge and another at 6-8 } \\
\text { weeks postpartum. Control: } \\
\text { standard care with no debriefing } \\
\text { session }\end{array}$ & $\begin{array}{l}\text { EPDS }>12 \text { at } 12 \\
\text { weeks postpartum }\end{array}$ & \\
\hline Gorman $^{48}$ & $\begin{array}{l}\text { Randomisation performed with } \\
\text { random numbers table and } \\
\text { blocking strategy based on } \\
\text { presence or absence of current or } \\
\text { past history of depression. } \\
\text { Outcome data collected via } \\
\text { interview and mailed } \\
\text { questionnaires. Attrition rate } 18 \% \\
\text { at } 24 \text { weeks }\end{array}$ & $\begin{array}{l}45 \text { pregnant women ( } 24 \text { in } \\
\text { intervention; } 21 \text { in control) at risk } \\
\text { of postnatal depression attending } \\
\text { various obstetric clinics in lowa } \\
\text { City and St Louis, US }\end{array}$ & $\begin{array}{l}\text { Intervention: five individual } \\
\text { sessions based on interpersonal } \\
\text { psychotherapy, beginning in late } \\
\text { pregnancy and ending at about } \\
\text { four weeks after birth }\end{array}$ & $\begin{array}{l}\text { EPDS }>12 \text { and SCID } \\
\text { at } 4 \text { and } 24 \text { weeks } \\
\text { postpartum }\end{array}$ & \\
\hline Gunn $^{59}$ & $\begin{array}{l}\text { Randomisation performed via } \\
\text { telephone through centrally } \\
\text { controlled randomisation centre. } \\
\text { Power analysis conducted and } \\
\text { outcome data collected via mailed } \\
\text { questionnaires. Attrition rate } 34 \% \\
\text { at } 24 \text { weeks }\end{array}$ & $\begin{array}{l}683 \text { healthy mothers (Nos in each } \\
\text { group not stated) who gave birth } \\
\text { in one rural and one metropolitan } \\
\text { hospital in Victoria, Australia. } \\
\text { Women excluded if they were } \\
\text { patients of general practitioners } \\
\text { who were trial reference group, } \\
\text { attended teenage clinic, or } \\
\text { delivered by emergency caesarean } \\
\text { section }\end{array}$ & $\begin{array}{l}\text { All participants received letter and } \\
\text { appointment date to see general } \\
\text { practitioner for checkup: } \\
\text { intervention group for } 1 \text { week } \\
\text { after hospital discharge and } \\
\text { control group for } 6 \text { weeks } \\
\text { postpartum }\end{array}$ & $\begin{array}{l}\text { EPDS }>12 \text { at } 12 \text { and } \\
24 \text { weeks }\end{array}$ & \\
\hline Lavender $^{61}$ & $\begin{array}{l}\text { Randomisation performed with } \\
\text { computer generated numbers and } \\
\text { consecutively numbered, sealed } \\
\text { opaque envelops. Power analysis } \\
\text { conducted and outcome data } \\
\text { collected via mailed questionnaire. } \\
\text { Attrition rate } 5 \% \text { at three weeks }\end{array}$ & $\begin{array}{l}114 \text { primiparous mothers ( } 60 \text { in } \\
\text { intervention; } 60 \text { in control) in UK } \\
\text { teaching hospital. Inclusion } \\
\text { criteria: singleton pregnancy, } \\
\text { cephalic presentation, } \\
\text { spontaneous labour at term, } \\
\text { normal vaginal delivery }\end{array}$ & $\begin{array}{l}\text { Intervention: one debriefing } \\
\text { session lasting } 30-120 \text { minutes } \\
\text { before hospital discharge, } \\
\text { provided by midwife with no } \\
\text { formal training } \\
\text { Control: standard care with no } \\
\text { debriefing session }\end{array}$ & $\begin{array}{l}\text { HADS }>10 \text { at } 3 \\
\text { weeks postpartum }\end{array}$ & $\begin{array}{l}\text { Atypical population, } 60 \% \text { were } \\
\text { single mothers }\end{array}$ \\
\hline MacArthur $^{56}$ & $\begin{array}{l}\text { Cluster design-randomisation } \\
\text { performed with customised, } \\
\text { computer program in independent } \\
\text { clinical trials unit. } 17 \text { practices } \\
\text { randomised to intervention and } 19 \\
\text { were to control. Power analysis } \\
\text { conducted and outcome data } \\
\text { collected via mailed } \\
\text { questionnaires. Attrition rate } 27 \% \\
\text { at } 16 \text { weeks }\end{array}$ & $\begin{array}{l}2064 \text { UK mothers ( } 1087 \text { in } \\
\text { intervention; } 977 \text { in control). } \\
\text { Excluded mothers expected to } \\
\text { move out of general practice area }\end{array}$ & $\begin{array}{l}\text { Intervention: flexible, } \\
\text { individualised, extended home } \\
\text { visits by midwife to } 28 \text { days } \\
\text { postpartum that included } \\
\text { screening with symptoms } \\
\text { checklist and EPDS; referral to } \\
\text { general practitioner as necessary' } \\
\text { and } 10-12 \text { week discharge visit } \\
\text { Control: standard care, included } \\
\text { seven midwifery home visits to } \\
10-14 \text { days postpartum (may } \\
\text { extend to } 28 \text { days) and care by } \\
\text { health visitors thereafter. General } \\
\text { practitioners completed routine } \\
\text { home visits and final check up at } \\
6-8 \text { weeks postpartum }\end{array}$ & $\begin{array}{l}\text { EPDS }>12 \text { at } 16 \\
\text { weeks postpartum }\end{array}$ & \\
\hline
\end{tabular}




\begin{tabular}{|c|c|c|c|c|c|}
\hline Study & Methods (all RCTs) & Participants & Interventions & Outcome & Notes \\
\hline Morrel| ${ }^{57}$ & $\begin{array}{l}\text { Randomisation performed with } \\
\text { random numbers table and } \\
\text { consecutively numbered, sealed } \\
\text { opaque envelopes. Power analysis } \\
\text { conducted and outcome data } \\
\text { collected via mailed } \\
\text { questionnaires. Attrition rate } 21 \% \\
\text { at } 24 \text { weeks }\end{array}$ & $\begin{array}{l}623 \text { UK mothers (311 in } \\
\text { intervention; } 312 \text { in control). } \\
\text { Exclusion criteria: insufficient } \\
\text { English to complete } \\
\text { questionnaires and infant in } \\
\text { special care unit for }>48 \text { hours }\end{array}$ & $\begin{array}{l}\text { Intervention: postnatal care at } \\
\text { home by community midwives } \\
\text { plus up to } 10 \text { home visits in first } \\
\text { month postpartum lasting up to } 3 \\
\text { hours provided by community } \\
\text { postnatal support worker } \\
\text { Control: postnatal care at home } \\
\text { by community midwives }\end{array}$ & $\begin{array}{l}\text { EPDS }>12 \text { at } 6 \text { and } \\
24 \text { weeks } \\
\text { postpartum }\end{array}$ & \\
\hline Priest $^{62}$ & $\begin{array}{l}\text { Randomisation performed within } \\
\text { strata of parity and mode of } \\
\text { delivery. Each woman selected } \\
\text { envelope from group of at least } \\
\text { six sealed, opaque envelopes } \\
\text { containing random allocation. } \\
\text { Power analysis conducted and } \\
\text { outcome data collected via mailed } \\
\text { questionnaires. Attrition rate } 19 \% \\
\text { at } 52 \text { weeks }\end{array}$ & $\begin{array}{l}1745 \text { Australian mothers ( } 875 \text { in } \\
\text { intervention; } 870 \text { in control). } \\
\text { Exclusion criteria: insufficient } \\
\text { English to complete } \\
\text { questionnaires, being under } \\
\text { psychological care at time of } \\
\text { delivery, mother aged }<18 \text { years, } \\
\text { and infant needing neonatal } \\
\text { intensive care }\end{array}$ & $\begin{array}{l}\text { Intervention: single, standardised } \\
\text { debriefing session provided in } \\
\text { hospital immediately after } \\
\text { randomisation or next day; } \\
\text { duration ranged from } 15 \text { minutes } \\
\text { to } 1 \text { hour and all research } \\
\text { midwives received training in } \\
\text { critical incident stress debriefing } \\
\text { Control: standard postpartum care }\end{array}$ & $\begin{array}{l}\text { EPDS }>12 \text { at } 8,24, \\
\text { and } 52 \text { weeks } \\
\text { postpartum }\end{array}$ & \\
\hline $\operatorname{Reid}^{55}$ & $\begin{array}{l}2 \times 2 \text { factorial design, } \\
\text { randomisation performed with } \\
\text { computer generated scheme with } \\
\text { randomised permuted blocks, } \\
\text { stratified by centre. Power } \\
\text { analysis conducted and outcome } \\
\text { data collected via mailed } \\
\text { questionnaires. Attrition rate } 29 \% \\
\text { at } 24 \text { weeks }\end{array}$ & $\begin{array}{l}1004 \text { UK mothers (503 in } \\
\text { intervention; } 501 \text { in control). All } \\
\text { primiparous women attending } \\
\text { antenatal clinics in two } \\
\text { participating hospitals. Women } \\
\text { whose infant subsequently died } \\
\text { or was admitted to the special } \\
\text { care unit for }>2 \text { weeks were } \\
\text { excluded }\end{array}$ & $\begin{array}{l}\text { Two postpartum interventions } \\
\text { incorporating four groups: } \\
\text { control, mailed self help materials, } \\
\text { invitation to support group, and } \\
\text { self help materials plus invitation } \\
\text { to support group. Data analysed } \\
\text { by pooling four groups as self } \\
\text { help } v \text { no self help and support } \\
\text { group } v \text { no support group. } \\
\text { Support groups run on weekly } \\
\text { basis for two hours, facilitated by } \\
\text { trained midwives }\end{array}$ & $\begin{array}{l}\text { EPDS }>11 \text { at } 12 \text { and } \\
24 \text { weeks } \\
\text { postpartum }\end{array}$ & $\begin{array}{l}\text { For this review, only support } \\
\text { group } v \text { no support group } \\
\text { comparisons were included. Only } \\
18 \% \text { of participants in } \\
\text { intervention group attended } \\
\text { support group session }\end{array}$ \\
\hline Small $^{60}$ & $\begin{array}{l}\text { Randomisation performed via } \\
\text { telephone with computer } \\
\text { generated randomisation schedule } \\
\text { for each midwife. Power analysis } \\
\text { conducted and outcome data } \\
\text { collected via mailed questionnaire. } \\
\text { Attrition rate } 12 \% \text { at } 24 \text { weeks }\end{array}$ & $\begin{array}{l}1041 \text { mothers ( } 520 \text { in } \\
\text { intervention; } 521 \text { in control) who } \\
\text { had operative delivery in large } \\
\text { maternity teaching hospital in } \\
\text { Melbourne, Australia }\end{array}$ & $\begin{array}{l}\text { Intervention: midwife-led } \\
\text { debriefing session before } \\
\text { discharge to provide women with } \\
\text { opportunity to discuss their } \\
\text { labour, birth, and events and } \\
\text { experiences after delivery } \\
\text { Control: standard care, included } \\
\text { brief visit from midwife on } \\
\text { discharge to give pamphlet on } \\
\text { sources of assistance }\end{array}$ & $\begin{array}{l}\text { EPDS }>12 \text { at } 24 \\
\text { weeks postpartum }\end{array}$ & \\
\hline Stamp $^{53}$ & $\begin{array}{l}\text { Randomisation performed with } \\
\text { consecutively numbered, sealed } \\
\text { opaque envelopes with } \\
\text { stratification by parity. Power } \\
\text { analysis conducted and outcome } \\
\text { data collected via mailed } \\
\text { questionnaire. Attrition rate } 13 \% \\
\text { at } 24 \text { weeks }\end{array}$ & $\begin{array}{l}144 \text { pregnant women ( } 73 \text { in } \\
\text { intervention; } 71 \text { in control) } \\
\text { screened for risk of postnatal } \\
\text { depression during antenatal clinic } \\
\text { visits in Adelaide, Australia. } \\
\text { Inclusion criteria: } \\
\text { English-speaking, singleton fetus, } \\
\text { and }<24 \text { weeks' gestation }\end{array}$ & $\begin{array}{l}\text { Intervention: routine antenatal } \\
\text { care plus two antenatal and one } \\
\text { postnatal midwife-led group } \\
\text { sessions } \\
\text { Control: routine antenatal and } \\
\text { postnatal care, which included } \\
\text { class at six weeks postpartum } \\
\text { that incorporated video on } \\
\text { postnatal depression }\end{array}$ & $\begin{array}{l}\text { EPDS }>12 \text { at } 6,12, \\
\text { and } 24 \text { weeks } \\
\text { postpartum }\end{array}$ & $\begin{array}{l}\text { High number of women screened } \\
\text { "vulnerable" and only } 31 \% \text { of } \\
\text { participants in intervention group } \\
\text { attended all three sessions }\end{array}$ \\
\hline $\mathrm{Tam}^{50}$ & $\begin{array}{l}\text { Randomisation performed with } \\
\text { random numbers table and } \\
\text { consecutively numbered, sealed, } \\
\text { opaque envelopes. Power analysis } \\
\text { conducted and outcome data } \\
\text { collected via interview and mailed } \\
\text { questionnaires. Attrition rate } 21 \% \\
\text { at } 6 \text { weeks }\end{array}$ & $\begin{array}{l}560 \text { Chinese mothers in hospital } \\
\text { ( } 280 \text { in each group) with at least } \\
\text { one suboptimal outcome in } \\
\text { perinatal period ranging from } \\
\text { antenatal complications requiring } \\
\text { admission, elective caesarean } \\
\text { section, labour induction, } \\
\text { postpartum haemorrhage, infant } \\
\text { admission to special care unit, etc }\end{array}$ & $\begin{array}{l}\text { Intervention: routine postpartum } \\
\text { care plus } 1-4 \text { sessions of } \\
\text { "educational counselling" by } \\
\text { research nurse before hospital } \\
\text { discharge that included } \\
\text { information related to adverse } \\
\text { event and counselling to assist } \\
\text { mother to "come to terms with } \\
\text { her losses and find solutions to } \\
\text { specific difficulties" (median total } \\
\text { time } 35 \text { minutes). Twenty four } \\
\text { women also received one session } \\
\text { with physician }\end{array}$ & $\begin{array}{l}\text { HADS }>4 \text { at } 6 \text { weeks } \\
\text { postpartum }\end{array}$ & $\begin{array}{l}\text { Health professionals not blinded } \\
\text { to group allocation }\end{array}$ \\
\hline Waldenstrom $^{58}$ & $\begin{array}{l}\text { Randomisation performed via } \\
\text { telephone with consecutively } \\
\text { numbered, sealed, opaque } \\
\text { envelopes. Power analysis } \\
\text { conducted and outcome data } \\
\text { collected via mailed } \\
\text { questionnaires. Attrition rate } 7 \% \\
\text { at } 8 \text { weeks }\end{array}$ & $\begin{array}{l}1000 \text { pregnant low risk mothers } \\
\text { ( } 495 \text { in intervention; } 505 \text { in } \\
\text { control) attending antenatal clinic } \\
\text { in Melbourne, Australia. Inclusion } \\
\text { criteria: > } 25 \text { weeks' gestation, } \\
\text { English-speaking, and low medical } \\
\text { risk }\end{array}$ & $\begin{array}{l}\text { Intervention: team midwifery care } \\
\text { provided antenatally and } \\
\text { postnatally in hospital with focus } \\
\text { on continuity } \\
\text { Control: standard antenatal and } \\
\text { postnatal care by physicians and } \\
\text { midwives with no focus on } \\
\text { continuity }\end{array}$ & $\begin{array}{l}\text { EPDS }>12 \text { at } 8 \\
\text { weeks postpartum }\end{array}$ & $\begin{array}{l}\text { Demographic differences found } \\
\text { between responders and } \\
\text { non-responders }\end{array}$ \\
\hline Zlotnick ${ }^{49}$ & $\begin{array}{l}\text { Unclear randomisation process. } \\
\text { Outcome data collected via } \\
\text { interview. Attrition rate } 6 \% \text { at } 12 \\
\text { weeks }\end{array}$ & $\begin{array}{l}37 \text { pregnant women (17 in } \\
\text { intervention; } 18 \text { in control) on } \\
\text { public assistance who had at least } \\
\text { one risk factor for postnatal } \\
\text { depression and were attending } \\
\text { prenatal clinic at general hospital } \\
\text { in northeast US }\end{array}$ & $\begin{array}{l}\text { Intervention: Survival Skills for } \\
\text { New Moms, which involved four } \\
60 \text { minute group sessions over } \\
\text { four weeks based on principles of } \\
\text { interpersonal psychotherapy } \\
\text { Control: standard antenatal care }\end{array}$ & $\begin{array}{l}\text { SCID at } 12 \text { weeks } \\
\text { postpartum }\end{array}$ & $\begin{array}{l}50 \% \text { of eligible women declined } \\
\text { to participate; } 77 \% \text { of participants } \\
\text { were single women }\end{array}$ \\
\hline
\end{tabular}

RCT=randomised controlled trial; EPDS=Edinburgh postnatal depression scale; HADS=hospital anxiety depression scale; SCID=structured clinical interview for DSM-IV.

Onset of intervention -Studies in which the intervention began antenatally and continued postnatally failed to reduce the likeli- hood of women developing postnatal depression (four trials, $\mathrm{n}=1283 ; 1.21,0.93$ to 1.59 ). However, there was a preventive 
effect in those trials evaluating a postnatal only intervention (10 trials, $\mathrm{n}=6379 ; 0.76,0.58$ to 0.98 ).

Effect of sample selected-Trials that selected participants considered to be "at risk" had more success in preventing postnatal depression (seven trials, $\mathrm{n}=1162 ; 0.67,0.51$ to 0.89 ) than those that enrolled women from the general population (eight trials, $\mathrm{n}=6535 ; 0.87,0.66$ to 1.16 ).

\section{Discussion}

This systematic review of the prevention of postnatal depression shows that there is no clear evidence to recommend the implementation of antenatal and postnatal classes, early postpartum follow-up, continuity of care models, psychological debriefing in hospital, and interpersonal psychotherapy. There is emerging evidence, however, to support the importance of additional professional support provided postnatally. Although one well designed trial suggested that intensive home visits by nurses with at risk mothers was protective during the first six weeks postpartum, ${ }^{51}$ the benefit was not maintained to 16 weeks. It is noteworthy that the 16 week assessment coincided with a decrease from weekly to monthly visits. Results from a cluster randomised controlled trial showed that flexible, individualised postpartum care by midwives that incorporated assessment tools also had a preventive effect. ${ }^{56}$ Due to the cluster randomisation process, however, this trial may have been overweighted in the meta-analyses. The effectiveness of postpartum support provided by laypeople remains uncertain. ${ }^{57}$

The trials can be further classified into different categories depending on the target population: universal interventions are offered to all women, selective interventions are offered to women at increased risk of developing postnatal depression, and indicated interventions are offered to women who have been identified as depressed or probably depressed ${ }^{64}$ Though I did not include any trial that evaluated an indicated intervention, the results of a subgroup analysis to examine the effects of universal and selective interventions showed that identifying mothers with risk factors assisted in the prevention of postnatal depression. Currently there is no consistency in the identification of such women, and a review of 16 antenatal screening tools suggests that there is no measure with acceptable predictive validity to accurately identify women who will later develop postnatal

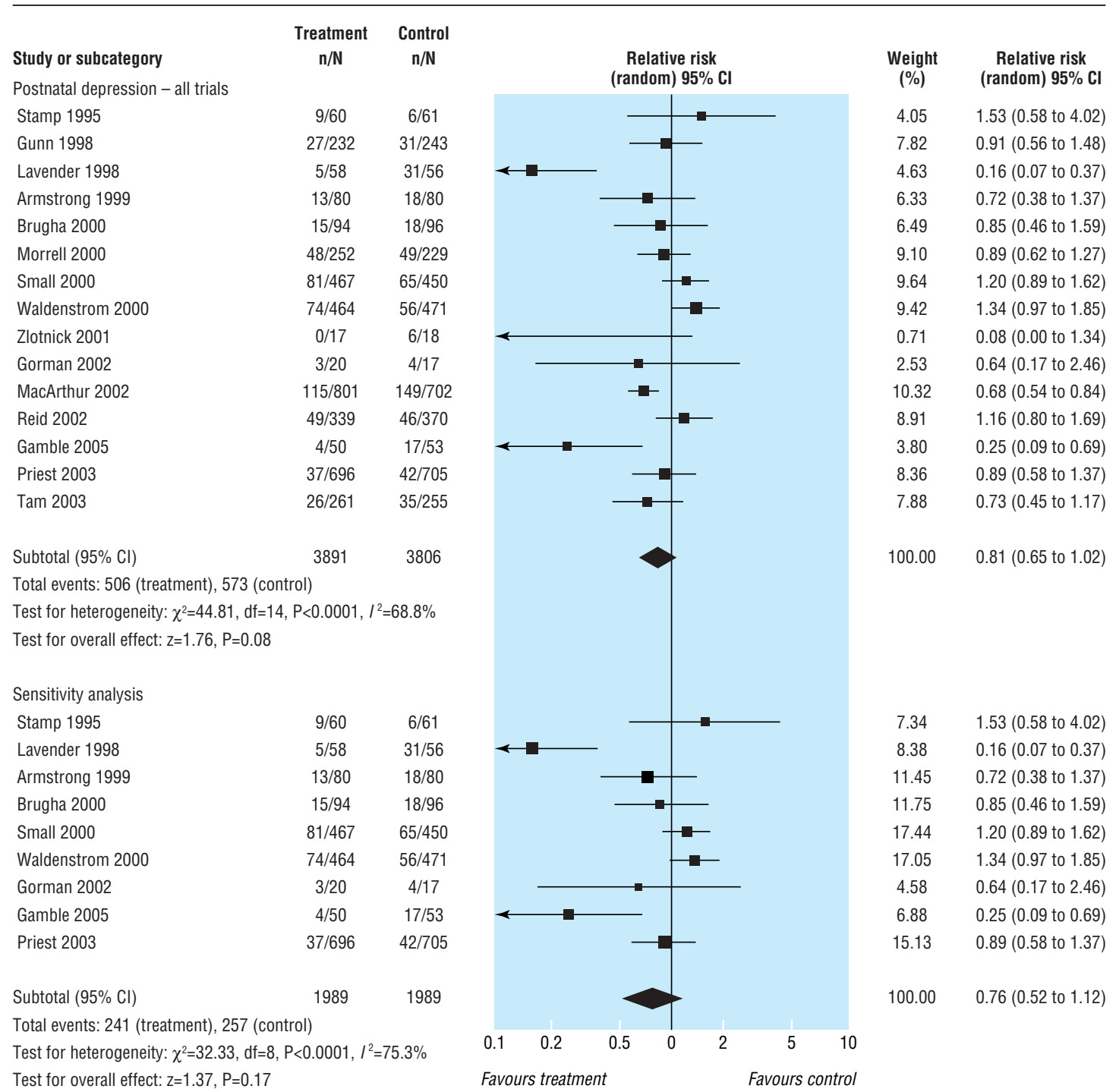

Fig 1 Postnatal depression at final assessment (variously defined) among studies evaluating interventions versus normal care in the prevention of postnatal depression 


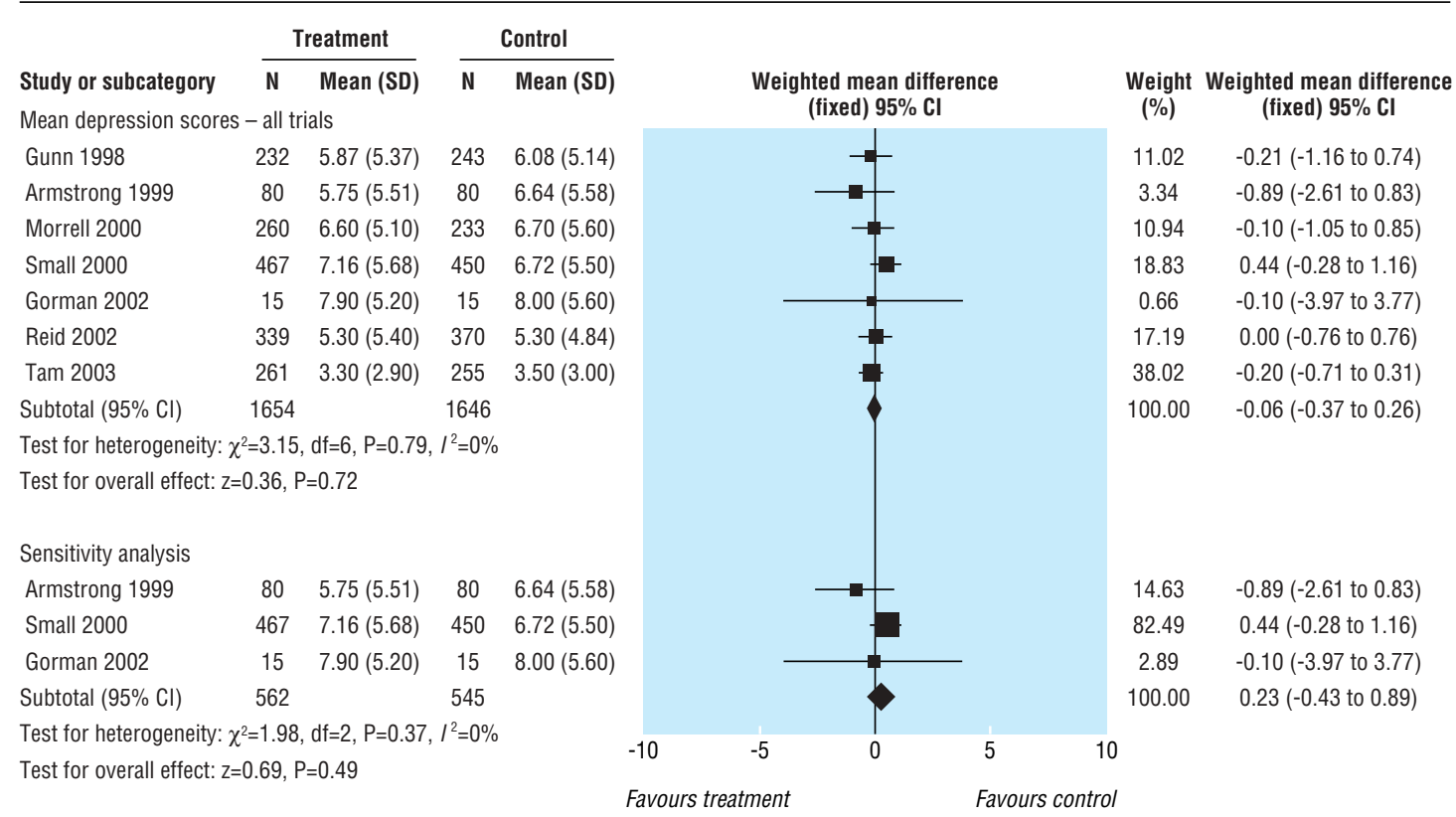

Fig 2 Mean depression scores at final assessment among studies evaluating interventions versus normal care in the prevention of postnatal depression

depression. ${ }^{65}$ This may partially explain why interventions with only a postnatal component seem to be more beneficial than interventions that also incorporate an antenatal component. Although I did not examine interaction effects between the five a priori subgroups, the estimates were independent and the sample sizes were large. ${ }^{66}$

The included trials were of good methodological quality. The reporting of the trials, however, was often not comprehensive, lacking details on the training and qualifications of the intervention providers and descriptions of adherence to the intervention protocol. There was also a failure to present details of the informational element of the interventions and on the background features of the care received by the control groups. While intention to treat analyses were performed, in trials with group sessions compliance was poor. ${ }^{52} 5355$

\section{What is already known on this topic}

Postnatal depression is a major health issue affecting about $13 \%$ of all new mothers

Epidemiological studies and meta-analyses of predictive studies have consistently found that several psychosocial and psychological variables contribute to increased risk

No systematic review has examined the preventive effect of psychosocial and psychological strategies or specific intervention characteristics

\section{What this study adds}

This study did not find sufficient evidence that diverse psychosocial or psychological interventions reduce the number of women who develop postnatal depression

Interventions that target at risk women, are individually based, or initiated postnatally are more likely to be beneficial

\section{Interpretation of results}

The diversity of preventive interventions and the widely differing study end points should urge some caution in the interpretation of the pooled data. To partially address this issue, I included short, intermediate, and longer term effects where appropriate. Despite this caution and the subgrouping of end points, this review consistently showed that women who received a preventive intervention were statistically overall just as likely to experience postnatal depression as those who received standard care. It is unknown to what extent some of the heterogeneity or non-significant results are related to the measure used to assess postnatal depression. A similar non-significant effect, however, was found among those trials that incorporated the Edinburgh postnatal depression scale.

The long term consequences of postnatal depression suggest preventive approaches are warranted. Translating research on risk factors into predictive screening protocols ${ }^{65}$ and preventive interventions, however, has met with limited success, as complex interactions of biopsychosocial risk factors with individual variations need to be considered. The results from this review provide physicians and other health professionals with recommendations for future preventive trials. To further investigate postnatal depression as a public health concern, the inclusion of ethnically and socioeconomically diverse women in these research efforts is critical. In addition, all future trials should include an economic analysis of the relative costs and benefits.

I thank L Gorman, R Hagan, and C MacArthur for responding to queries. Contributions: D Creedy assisted with assessment of trial quality and data entry, J Kavanagh assisted with the search strategy, and E Hodnett provided editorial suggestions.

Funding: None.

Competing interests: None declared.

Ethical approval: Not required.

1 Affonso DD, De AK, Horowitz JA, Mayberry LJ. An international study exploring levels of postpartum depressive symptomatology. J Psychosom Res 2000;49:207-16.

2 Oates MR, Cox JL, Neema S, Asten P, Glangeaud-Freudenthal N, Figueiredo B, et al. Postnatal depression across countries and cultures: a qualitative study. Br J Psychiatry Suppl 2004;46:s10-6. 
3 O'Hara M, Swain A. Rates and risk of postpartum depression-a meta-analysis. Int Rev Psychiatry 1996;8:37-54

4 Cooper PJ, Murray L. Fortnightly review. Postnatal depression. BMJ 1998;316:1884-6.

5 Cooper PJ, Murray L. Course and recurrence of postnatal depression. Evidence for the specificity of the diagnostic concept. Br J Psychiatry 1995;166:191-5.

6 Cooper P, Murray L. Prediction, detection, and treatment of postnatal depression. Arch Dis Child 1997;77:97-9.

7 Beck CT. Predictors of postpartum depression: an update. Nursing Res 2001;50:275-85.

8 Bernazzani O, Saucier JF, David H, Borgeat F. Psychosocial predictors of depressive symptomatology level in postpartum women. J Affect Disord 1997;46:39-49.

9 O'Hara MW, Schlechte JA, Lewis DA, Varner MW. Controlled prospective study of postpartum mood disorders: psychological, environmental, and hormonal variables. $J$ $100 \cdot 63-73$

10 Gotlib IH, Whiffen VE, Wallace PM, Mount JH. Prospective investigation of postpartum depression: factors involved in onset and recovery. J Abnormal Psychology
1991;100:122-32.

11 Mills EP, Finchilescu G, Lea SJ. Postnatal depression-an examination of psychosocia factors. S Afr Med J 1995;85:99-105.

12 Cooper PJ, Murray L. Postnatal depression. BMJ 1998;316:1884-6.

13 Brugha TS, Sharp HM, Cooper SA, Weisender C, Britto D, Shinkwin R, et al. The Leicester 500 project. Social support and the development of postnatal depressive symptoms, a prospective cohort survey. Psychol Med 1998;28:63-79.

14 Righetti-Veltema M, Conne-Perreard E, Bousquet A, Manzano J. Risk factors and predighetti-Veltema M, Conne-Perreard E, Bousquet A, Manzano J. R
digns of postpartum depression. J Affect Dis 1998;49:167-80.

15 Dennis CL, Janssen PA, Singer J. Identifying women at-risk for postpartum depression in the immediate postpartum period. Acta Psychiatr Scand 2004;110:338-46.

16 Dennis CL. Treatment of postpartum depression. 2: a critical review of nonbiological interventions. J Clin Psychiatry 2004;65:1252-65.

17 Dennis CL. Preventing postpartum depression. I: a review of biological interventions. Can J Psychiatry 2004;49:467-75.

18 Dennis CL. Preventing postpartum depression. II: A critical review of nonbiological interventions. Can J Psychiatry 2004;49:526-38.

19 Lumley J, Austin MP, Mitchell C. Intervening to reduce depression after birth: a systematic review of the randomized trials. Int J Technol Assess Health Care 2004;20: $128-44$.

20 Dennis CL, Creedy D. Psychosocial and psychological interventions for preventing postpartum depression. Cochrane Database Syst Rev 2004;(4):CD001134.

21 Higgins JP, Thompson SG. Quantifying heterogeneity in a meta-analysis. Stat Med 2002;21:1539-58.

22 Chabrol H, Teissedre F, Saint-Jean M, Teisseyre N, Roge B, Mullet E. Prevention and treatment of post-partum depression: a controlled randomized study on women at risk. Psychol Med 2002;32:1039-47.

23 Elliott SA, Leverton TJ, Sanjack M, Turner H, Cowmeadow P, Hopkins J, et al. Promoting mental health after childbirth: a controlled trial of primary prevention of postnatal depression. Br J Clin Psychol 2000;39:223-41.

24 Gordon R, Gordon K. Social factors in prevention of postpartum emotional problems. Obstet Gynecol 1960;15:433-8.

25 Serwint JR, Wilson MH, Duggan AK, Mellits ED, Baumgardner RA, DeAngelis C. Do postpartum nursery visits by the primary care provider make a difference? Pediatric postpartum nu

26 Buist A, Westley D, Hill C. Antenatal prevention of postnatal depression. Arch Women' Mental Health 1999;1:167-73

27 Marks MN, Siddle K, Warwick C. Can we prevent postnatal depression? A randomized controlled trial to assess the effect of continuity of midwifery care on rates of postnatal depression in high-risk women.J Matern Fetal Neonatal Med 2003;13:119-27.

28 Wolman WL, Chalmers BE, Hofmeyr J, Nikodem VC. Postpartum depression and companionship in the clinical birth environment: a randomized, controlled study. Am Obstet Gynecol 1993;168:1388-93.

29 Harris B, Oretti R, Lazarus J, Parkes A, John R, Richards C, et al. Randomised trial of thyroxine to prevent postnatal depression in thyroid-antibody-positive women. $\mathrm{Br} J$ Psychiatry 2002;180:327-30.

30 Harrison-Hohner J, Coste S, Dorato V, Curet LB, McCarron D, Hatton D. Prenatal calcium supplementation and postpartum depression: an ancillary study to a randomized trial of calcium for prevention of preeclampsia. Arch Women's Mental Healt 2001;3:141-6.

31 Hayes BA, Muller R, Bradley BS. Perinatal depression: a randomized controlled trial of an antenatal education intervention for primiparas. Birth 2001;28:28-35.

32 Heh SS, Fu YY. Effectiveness of informational support in reducing the severity of postnatal depression in Taiwan. J Adv Nurs 2003;42:30-6.

33 Llorente AM, Jensen CL, Voigt RG, Fraley JK, Berretta MC, Heird WC. Effect of maternal docosahexaenoic acid supplementation on postpartum depression and information processing. Am J Obstet Gymecol 2003;188:1348-53.

34 Lawrie TA, Hofmeyr GJ, De Jager M, Berk M, Paiker J, Viljoen E. A double-blind randomised placebo controlled trial of postnatal norethisterone enanthate: the effect on domised placebo controlled trial of postnatal norethisterone enanthate: the effect
postnatal depression and serum hormones. Br J Obstet Gynaecol 1998;105:1082-90.

35 Okano T, Nagata S, Hasegawa M, Nomura J, Kumar R. Effectiveness of antenatal education about postnatal depression: a comparison of two groups of Japanese mothers. J Mental Health 1998; $7: 191-8$

36 Rees BL. Effect of relaxation with guided imagery on anxiety, depression, and self-esteem in primiparas.J Holistic Nursing 1995;13:255-67.

37 Sichel DA, Cohen LS, Robertson LM, Ruttenberg A, Rosenbaum JF. Prophylactic estrogen in recurrent postpartum affective disorder. Biol Psychiatry 1995;38:814-8.

38 Webster J, Linnane J, Roberts J, Starrenburg S, Hinson J, Dibley L. Identify, educate an alert (IDEA) trial: an intervention to reduce postnatal depression. BJOG 2003;110:842-6.
39 Wisner KL, Wheeler SB. Prevention of recurrent postpartum major depression. Hospital Community Psychiatry 1994;45:1191-6.

40 Wisner KL, Perel JM, Peindl KS, Hanusa BH, Findling RL, Rapport D. Prevention of recurrent postpartum depression: a randomized clinical trial. J Clin Psychiatry 2001;62:82-6.

41 Gordon NP, Walton D, McAdam E, Derman J, Gallitero G, Garrett L. Effects of providing hospital-based doulas in health maintenance organization hospitals. Obstet Gynecol 1999;93:422-6.

42 Hodnett ED, Lowe NK, Hannah ME, Willan AR, Stevens B, Weston JA, et al. Effectiveness of nurses as providers of birth labor support in North American hospitals: a randness of nurses as providers of birth labor support

43 Lieu TA, Braveman PA, Escobar GJ, Fischer AF, Jensvold NG, Capra AM. A randomized comparison of home and clinic follow-up visits after early postpartum hospital discharge. Pediatrics 2000;105:1058-65.

44 Saisto T, Salmela-Aro K, Nurmi JE, Kononen T, Halmesmaki E. A randomized controlled trial of intervention in fear of childbirth. Obstet Gynecol 2001;98:820-6.

45 Shields N, Reid M, Cheyne H, Holmes A. Impact of midwife-managed care in the postnatal period: an exploration of psychosocial outcomes. J Reprod Infant Psychol 1997;15:91-108.

46 Spinelli MG. Interpersonal psychotherapy for depressed antepartum women: a pilot study. Am J Psychiatry 1997;154:1028-30.

47 Spinelli MG, Endicott J. Controlled clinical trial of interpersonal psychotherapy versus parenting education program for depressed pregnant women. Am J Psychiatry 2003; $160: 555-62$.

48 Gorman LL. Prevention of postpartum depression in a high risk sample. Iowa City, IA: University of Iowa, 2001

49 Zlotnick C, Johnson SL, Miller IW, Pearlstein T, Howard M. Postpartum depression in women receiving public assistance: pilot study of an interpersonal-therapy-oriented group intervention. Am J Psychiatry 2001;158:638-40.

50 Tam WH, Lee DT, Chiu HF, Ma KC, Lee A, Chung TK. A randomised controlled trial of educational counselling on the management of women who have suffered suboptimal outcomes in pregnancy. BJOG 2003;110:853-9.

51 Armstrong KL, Fraser JA, Dadds MR, Morris J. A randomized, controlled trial of nurse home visiting to vulnerable families with newborns. $J$ Paediatr Child Health 1999;35:237-44

52 Brugha TS, Wheatley S, Taub NA, Culverwell A, Friedman T, Kirwan P, et al. Pragmatic randomized trial of antenatal intervention to prevent post-natal depression by reducing psychosocial risk factors. Psychol Med 2000;30:1273-81.

53 Stamp GE, Williams AS, Crowther CA. Evaluation of antenatal and postnatal support to overcome postnatal depression: a randomized, controlled trial. Birth 1995;22: 138-43.

54 Gamble J, Creedy D, Moyle W, Webster J, McAllister M, Dickson P. Effectiveness of a counseling intervention after a traumatic childbirth: a randomized controlled trial. Birth 2005;32:11-9.

55 Reid M, Glazener C, Murray GD, Taylor GS. A two-centred pragmatic randomised controlled trial of two interventions of postnatal support. BJOG 2002;109:1164-70.

56 MacArthur C, Winter HR, Bick DE, Knowles H, Lilford R, Henderson C, et al. Effects of redesigned community postnatal care on women's health 4 months after birth: a cluster randomised controlled trial. Lancet 2002;359:378-85.

57 Morrell CJ, Spiby H, Stewart P, Walters S, Morgan A. Costs and effectiveness of community postnatal support workers: randomised controlled trial. BMJ 2000;321:593-8.

58 Waldenstrom U, Brown S, McLachlan H, Forster D, Brennecke S. Does team midwife care increase satisfaction with antenatal, intrapartum, and postpartum care? A randomized controlled trial. Birth 2000;27:156-67.

59 Gunn J, Lumley J, Chondros P, Young D. Does an early postnatal check-up improve maternal health: results from a randomised trial in Australian general practice? $B J O G$ 1998;105:991-7.

60 Small R, Lumley J, Donohue L, Potter A, Waldenstrom U. Randomised controlled trial of midwife led debriefing to reduce maternal depression after operative childbirth. BMJ 2000:321:1043-7.

61 Lavender T, Walkinshaw SA. Can midwives reduce postpartum psychological morbidity? A randomized trial. Birth 1998;25:215-9.

62 Priest SR, Henderson J, Evans SF, Hagan R. Stress debriefing after childbirth: a randomised controlled trial. Med J Aust 2003;178:542-5.

63 Cox JL, Holden JM, Sagovsky R. Detection of postnatal depression. Development of the 10-item Edinburgh postnatal depression scale. Br J Psychiatry 1987;150:782-6.

64 Mrazek PJ, Haggerty RJ. Reducing risks for metal disorders-frontiers for prevention intervention research. Washington, DC: National Academy Press, 1994.

65 Austin M, Lumley J. Antenatal screening for postnatal depression: a systematic review. Acta Psychiatr Scand 2003;107:10-7.

66 Altman DG, Bland JM. Interaction revisited: the difference between two estimates. BMJ 2003;326:219.

(Accepted 1 February 2005)

bmj.com 2005;331:15

University of Toronto, Faculty of Nursing, 50 St George Street, Toronto, ON,

Canada M5S 3H4

Cindy-Lee Dennis assistant professor

Correspondence to: C-L Dennis cindylee.dennis@utoronto.ca 